\title{
ANALYSIS OF THE INCLUSIVENESS OF THE ELEMENTARY TEACHER EDUCATION CURRICULUM IMPLEMENTED BY THE HIGHER EDUCATION COMMISSION, PAKISTAN
}

\author{
Muhammad Usman Zia \\ Lecturer, \\ Department of Special Education, University of Education, Faisalabad, \\ Punjab, Pakistan. \\ Email: othmanxia@gmail.com
}

\section{Fariha Gul,}

Assistant Professor,

Department of Education, Univeristy of Management and Technology

Lahore, Punjab, Pakistan

Email: fariha.gul@umt.edu.pk

\section{Muhammad Javed Aftab}

Lecturer,

Department of Special Education, University of Education, Lahore (Faisalabad Campus),

Faisalabad, Punjab, Pakistan

Email: drmjavedaftab@ue.edu.pk

\begin{abstract}
It seems imperative to analyze the existing teacher education curriculum at several levels to help curriculum developers in the field of teacher education to make future teacher education programs inclusive. For this purpose, the researchers analyzed the exiting elementary teacher education curriculum developed and implemented by the Higher Education Commission of Pakistan (2012) by utilizing a curriculum analysis checklist to indicate the evidence or non-evidence of inclusive concepts in the curriculum document. A panel of teacher educators analyzed the elementary teacher education curriculum and concluded that existing elementary teacher education does not help the teachers to prepare for the inclusion of children with disabilities in the regular classroom.
\end{abstract}

\section{KEYWORDS}

Inclusive Education, Elementary, Teacher Education, Disabilities, Curriculum 
INTRODUCTION

The Constitution of the Islamic Republic of Pakistan requires the state to provide free provision of education to all children of a specific age. Children with disabilities are also included in the "all" children to which education shall be provided but on the ground situation of access to schools is not satisfactory as approximately $96 \%$ of children with disabilities are deprived of schooling (Manzoor \& Hameed, 2016). Ministry of Federal Education \& Professional Training (2017) indicated that one of the major reasons for the exclusion of children with disabilities from the right to access to education is unfriendly schools at the doorstep. Literature has suggested that the focus of inclusive education is on educating all children while respecting their diversity in abilities, needs, and learning expectations (Lautenbach \& Heyder, 2019). It is argued that inclusive education is not the matter of physical integration of the marginalized in regular school but it is emotional, social, and cultural integration of children with varied learning abilities and needs which has ignited a need for changes in teacher education programs across the globe (Lautenbach \& Heyder, 2019; Van Mieghem et al., 2020). To successfully implement inclusive education, it is required that the teacher must reconsider their teaching practices. It has been noted that many teachers do not feel competent enough to change their teaching practices to meet the needs of diverse learners in a heterogeneous classroom (Loreman, 2014; Van Mieghem et al., 2020). Studies (Thakur \& Abbas, 2017. Evmenova \& Zia, 2018) indicate that teacher education is one of the major reasons which keep children with disabilities out of school. Teachers who are working at the regular elementary education level are neither fully aware of child diversity nor have the ability to accommodate children with disabilities in their regular classrooms. In some past studies (Pasha, 2012 \& Fazal 2012) school readiness for inclusion in Pakistan was studied which also indicated that teachers are not ready or capable of accommodating children with disabilities in regular classrooms.

It seems understandable that teacher education programs in Pakistani teacher education institutions are not ready to prepare teachers who are capable of accommodating children with disabilities in a regular classroom. Pakistani teacher education institutions follow the teacher education curriculum introduced by the Higher Education Commission for preparation of the future teachers. The present study was intended to identify gaps in the existing elementary teacher education curriculum being utilized to educate the prospective teachers at the elementary level in Pakistan.

Literature indicates that an inclusive teacher must possess an attitude of respecting diversity, creating adaptive education experiences, and accommodating individual needs as well as the ability to work in teams and with others to create an enabling environment (Atta, Shah \& Khan, 2009). Whitworth (1999) argues that to make a teacher inclusive, a teacher preparation program must focus on the outcomes such as 
understanding diversity, adapting to change, and flexibility. The core areas of competence for an inclusive teacher education program include valuing learner diversity, supporting all learners by adapting curriculum, working with others to create enabling environment, and personal professional development (European Agency for Development in Special Needs Education, 2012). Therefore, the conceptual framework of this study revolved around four areas of competence expected to be inculcated by the teacher education curriculum in the regular school teachers to prepare them for inclusion. These areas of competence include:

1. Understanding the disability

2. Ability to adapt the curriculum to meet the needs of students with disabilities in the regular classroom

3. Working in collaboration with parents and professionals to create enabling educational environment

4. Personal professional development to meet the ever-emerging needs of students with disabilities.

These four areas of competence are reflected in the questions this study has intended to answer.

\section{LITERATURE REVIEW}

Florin \& Chamber (2017) argue that the evolution of schooling from segregation to inclusion of children with special needs in heterogeneous classrooms has changed the role of teachers from traditional to more modern and inclusive. Rose (2010) states that inclusive education required general education teachers to be able to accommodate students with various needs in their regular classrooms. It is reported by the researchers that if teachers are not open and trained to inclusive education, then reforms in the education system to accommodate the children with special education needs are less likely to succeed (Beacham \& Rouse, 2012; Florin \& Chamber, 2017).

Studies (Thakur \& Abbas, 2017; Evmenova \& Zia, 2018) indicate that teacher education is one of the major reasons which keep children with disabilities out of school. Teachers who are working at regular elementary education levels are neither fully aware of child diversity nor can accommodate children with disabilities in their regular classrooms. In some past studies (Pasha, 2012 \&Fazal 2012) school readiness for inclusion in Pakistan was studied which also indicated that teachers are not ready or capable of accommodating children with disabilities in regular classrooms. As an integral part of the education system, teacher education programs play the primary role in the making of a teacher who steers the process of education (Samsujamman, 2017). On, international scale, a review of 26 studies indicated that most of the teachers in regular education hold non-supporting or negative attitudes towards inclusive education (Boer, Pijl \& Minnaert, 2011). 
Avramidis and Kalyva (2007) indicated that teachers having long-term specialized education about disability held positive attitudes toward inclusion. Ghanizadeh, Bahredar, and Moeini (2006) pointed out a positive relationship between education and knowledge about inclusion and teachers' attitudes. Batsiou et al. (2008) also found a significant correlation between knowledge and teachers' attitudes towards inclusive education. Boer, Pijl \& Minnaert, (2011) indicate that the teachers who received appropriate teacher education had more positive attitudes towards inclusive education as compared to those who did not have such type of education.

\section{RESEARCH OBJECTIVE}

1. Analyze the HEC elementary teacher education curriculum for identification of gaps regarding the inclusion of diverse students in a regular classroom.

\section{RESEARCH QUESTIONS}

1. Does the existing ETE curriculum contain the ingredient of human disabilities in the light of the human diversity model?

2. Does the existing ETE curriculum contain the ingredient of curriculum adaptation for the accommodation of children with disabilities in a regular classroom?

3. Does the existing ETE curriculum contain the ingredient of collaboration for the inclusion of children with disabilities?

4. Does the existing ETE curriculum contain the ingredient of personal/ professional development for the inclusion of children with disabilities?

\section{RESEARCH METHODOLOGY}

To answer the questions of the study, the curriculum analysis of the HEC elementary teacher education was carried out. Jensen \& Reddy (1994) and Ariav (1986) define curriculum analysis as a systematic attempt to uncover the underlying paradigm, beliefs, or assumptions. It also finds out the strengths and weaknesses of the curriculum to facilitate decision-making (Ariav, 1986). The process of curriculum analysis must be guided by a scheme well familiar to the analyst. Curriculum analysis also identifies blind spots, biases, and perspectives (Jensen \& Reddy, 1994). The curriculum analysis was carried out with the help of a curriculum analysis checklist. The response mechanism for the checklist was based on a three-point scale ranging from 1 to 3 . Where 1 indicated "not evident", 2 indicated "somewhat evident" and 3 indicated "clearly evident" (Welsh \& D'Agostino, 2009, McMillan, 2013). If a concept was found to be evident during the analysis, the course, topic, and page number in which the concept was evident were also indicated. The checklist was validated by a panel of experts by utilizing the Content Validity Ratio (CVR). Value of Content Validity Ratio (CVR) helps the researchers to retain or reject an item from the instrument based upon the opinion of experts. The value of CVR ranges from .00 to .99 which indicates the response of experts on certain items. An item gaining a CVR value of more than $50 \%$ 
is retained in the instrument (Ayre \& Scally, 2014, Gull, 2015). A panel of five teacher educators from public and private universities of Punjab was purposefully selected to analyze the curriculum with the help of the curriculum analysis checklist.

\section{DATA ANALYSIS AND RESULTS}

Pakistani teacher education institutes follow the "Curriculum of Education: B.Ed (Hons.) Elementary, Associate Degree in Education (2012)" for elementary teacher education. The HEC elementary teacher education curriculum was developed by National Curriculum Review Committee (NCRC) in 2010. The same curriculum was reviewed and revised in 2012 by NCRC at Karachi University. The structure of the curriculum is presented in the following table.

Table No 1: Structure of the B.Ed. Elementary Curriculum Scheme

\begin{tabular}{cc}
\hline Courses & Credit Hours \\
\hline Compulsory Courses & 19 \\
Professional Courses & 51 \\
Foundation Courses & 24 \\
Content Courses & 26 \\
Teaching Practice & 15 \\
Total Credit Hours & 135 \\
\hline
\end{tabular}

The first objective of the present study was to analyze the curriculum. A curriculum analysis checklist was developed and validated for this purpose. The curriculum analysis checklist was based upon four factors of inclusive teacher education as identified in the literature which includes

1. Student: Concept of the students with disabilities

2. Curriculum: the concept of curriculum adaptation and inclusive curricular practices

3. Context: the concept of working in collaboration with parents and professionals to create enabling educational environments

4. Teacher: the context of personal professional development to meet the emerging pedagogical challenges for inclusion

These four factors were translated into varying numbers of indicators under each factor. Five teacher educators from different public and private sector universities (see Annexure) were requested to read the HEC elementary teacher education curriculum and fill the curriculum analysis checklist. In case of the evidence of an indicator in the curriculum, the course, topic, and page number were also identified. Evidence or nonevidence of the indicators are depicted in the following tables.

Table No 2: Evidence of the concept on the learners with disabilities in the HECETE curriculum 
PJER, Vol 4, Issue 4 (2021)

Analysis of the...

\begin{tabular}{|c|c|c|c|c|c|c|c|}
\hline Indicators & $\begin{array}{l}\text { Not } \\
\text { Evide } \\
\text { nt }\end{array}$ & $\begin{array}{l}\text { Somew } \\
\text { hat } \\
\text { Eviden } \\
\text { t }\end{array}$ & $\begin{array}{c}\text { Clear } \\
\text { ly } \\
\text { Evide } \\
\text { nt }\end{array}$ & Course & Topic & $\begin{array}{c}\text { Pa } \\
\text { ge } \\
\text { No. }\end{array}$ & $\begin{array}{c}\text { No. of } \\
\text { Respond } \\
\text { ents }\end{array}$ \\
\hline $\begin{array}{l}\text { Concept of } \\
\text { Human } \\
\text { Diversity }\end{array}$ & & $\mathrm{X}$ & & $\begin{array}{l}\text { School, } \\
\text { Communi } \\
\text { ty and } \\
\text { Teacher }\end{array}$ & $\begin{array}{l}\text { Cultural } \\
\text { Diversity }\end{array}$ & 210 & 3 \\
\hline $\begin{array}{l}\text { Concept of } \\
\text { Human } \\
\text { Disabilities }\end{array}$ & & $X$ & & $\begin{array}{l}\text { Child } \\
\text { developm } \\
\text { ent }\end{array}$ & $\begin{array}{l}\text { Differenc } \\
\text { es in } \\
\text { develop } \\
\text { ment and } \\
\text { special } \\
\text { needs }\end{array}$ & 50 & 4 \\
\hline $\begin{array}{l}\text { Concept of } \\
\text { Inclusion } \\
\text { of children } \\
\text { with } \\
\text { disabilities } \\
\text { in } \\
\text { mainstream } \\
\text { life }\end{array}$ & & $X$ & & $\begin{array}{l}\text { Child } \\
\text { developm } \\
\text { ent }\end{array}$ & $\begin{array}{l}\text { Differenc } \\
\text { es in } \\
\text { develop } \\
\text { ment and } \\
\text { special } \\
\text { needs }\end{array}$ & 50 & 3 \\
\hline $\begin{array}{l}\text { Concept of } \\
\text { Inclusive } \\
\text { Education }\end{array}$ & & $X$ & & $\begin{array}{l}\text { Child } \\
\text { Develop } \\
\text { ment }\end{array}$ & $\begin{array}{l}\text { Addressi } \\
\text { ng } \\
\text { Special } \\
\text { Needs in } \\
\text { Classroo } \\
\text { m }\end{array}$ & 51 & 4 \\
\hline $\begin{array}{l}\text { Concept of } \\
\text { equitable } \\
\text { access to } \\
\text { education }\end{array}$ & $X$ & & & & & & 5 \\
\hline $\begin{array}{l}\text { Concept of } \\
\text { understandi } \\
\text { ng the } \\
\text { educational } \\
\text { needs of } \\
\text { children } \\
\text { with } \\
\text { disabilities }\end{array}$ & $X$ & & & & & & 5 \\
\hline
\end{tabular}


PJER, Vol 4, Issue 4 (2021)

Analysis of the...

\begin{tabular}{|c|c|c|c|c|c|c|}
\hline $\begin{array}{l}\text { Understand } \\
\text { ing of } \\
\text { human } \\
\text { developme } \\
\text { nt }\end{array}$ & & $\bar{X}$ & $\begin{array}{l}\text { Child } \\
\text { Develop } \\
\text { ment }\end{array}$ & $\begin{array}{l}\text { All } \\
\text { topics }\end{array}$ & $\begin{array}{c}49- \\
51\end{array}$ & 5 \\
\hline $\begin{array}{l}\text { Understand } \\
\text { ing of } \\
\text { discrepanci } \\
\text { es in } \\
\text { human } \\
\text { developme } \\
\text { nt }\end{array}$ & $X$ & & $\begin{array}{l}\text { Child } \\
\text { developm } \\
\text { ent }\end{array}$ & $\begin{array}{l}\text { Differenc } \\
\text { es in } \\
\text { develop } \\
\text { ment and } \\
\text { special } \\
\text { needs }\end{array}$ & 50 & 5 \\
\hline $\begin{array}{l}\text { Concept of } \\
\text { teaching } \\
\text { students } \\
\text { with } \\
\text { disabilities } \\
\text { in regular } \\
\text { classroom }\end{array}$ & $X$ & & $\begin{array}{l}\text { Child } \\
\text { Develop } \\
\text { ment }\end{array}$ & $\begin{array}{l}\text { Addressi } \\
\text { ng } \\
\text { Special } \\
\text { Needs in } \\
\text { Classroo } \\
\mathrm{m}\end{array}$ & 51 & 4 \\
\hline $\begin{array}{l}\text { Concept of } \\
\text { accommod } \\
\text { ating the } \\
\text { needs of } \\
\text { students } \\
\text { with } \\
\text { disabilities } \\
\text { in regular } \\
\text { classroom }\end{array}$ & $X$ & & $\begin{array}{l}\text { Child } \\
\text { Develop } \\
\text { ment }\end{array}$ & $\begin{array}{l}\text { Addressi } \\
\text { ng } \\
\text { Special } \\
\text { Needs in } \\
\text { Classroo } \\
\mathrm{m}\end{array}$ & 51 & 4 \\
\hline
\end{tabular}

The above table indicates that concept of human diversity was somewhat evident in the form of cultural diversity in HEC-ETE curriculum in the course of school community and teacher development under the topic of cultural diversity. The concept of disabilities, inclusion of children with disabilities in mainstream education and concept of inclusive education were evident in the course of child development under the topic of differences in development and special needs. Concept of equitable access to education and unique needs of the learners with disabilities was not identified to be evident by any of the respondents. Concept of human development was evident in all chapters of the course of child development as identified by the respondents. Concept of understanding discrepancies in human development, concept of teaching students with disabilities in regular classroom and accommodating the needs of learners with disabilities in regular classroom was somewhat evident in the topic of addressing 
special needs in classroom in the course of child development. These concepts were not evident in any other course or topic of HEC elementary teacher education curriculum.

Table No 3: Evidence of the Concept of Curriculum Adaptation and Inclusive Curricular Practices in HEC-ETE Curriculum

\begin{tabular}{|c|c|c|c|c|c|c|c|}
\hline $\begin{array}{l}\text { Indicator } \\
\mathrm{S}\end{array}$ & $\begin{array}{l}\text { Not } \\
\text { Evid } \\
\text { ent }\end{array}$ & $\begin{array}{l}\text { Somew } \\
\text { hat } \\
\text { Eviden } \\
\text { t }\end{array}$ & $\begin{array}{c}\text { Clear } \\
\text { ly } \\
\text { Evid } \\
\text { ent }\end{array}$ & Course & Topic & $\begin{array}{c}\text { Pa } \\
\text { ge } \\
\text { No. }\end{array}$ & $\begin{array}{c}\text { No. of } \\
\text { Respond } \\
\text { ents }\end{array}$ \\
\hline $\begin{array}{l}\text { Concept } \\
\text { of } \\
\text { curriculu } \\
\mathrm{m} \\
\text { adaptation } \\
\text { for } \\
\text { students } \\
\text { with } \\
\text { disabilitie } \\
\text { s }\end{array}$ & $X$ & & & & & & 5 \\
\hline $\begin{array}{l}\text { Concept } \\
\text { of } \\
\text { adapting } \\
\text { content to } \\
\text { meet the } \\
\text { needs of } \\
\text { students } \\
\text { with } \\
\text { disabilitie } \\
\text { s }\end{array}$ & $X$ & & & & & & 5 \\
\hline $\begin{array}{l}\text { Concept } \\
\text { of } \\
\text { designing } \\
\text { the } \\
\text { instructio } \\
\mathrm{n} \text { to meet } \\
\text { the need } \\
\text { of } \\
\text { students } \\
\text { with }\end{array}$ & $X$ & & & & & & 5 \\
\hline
\end{tabular}




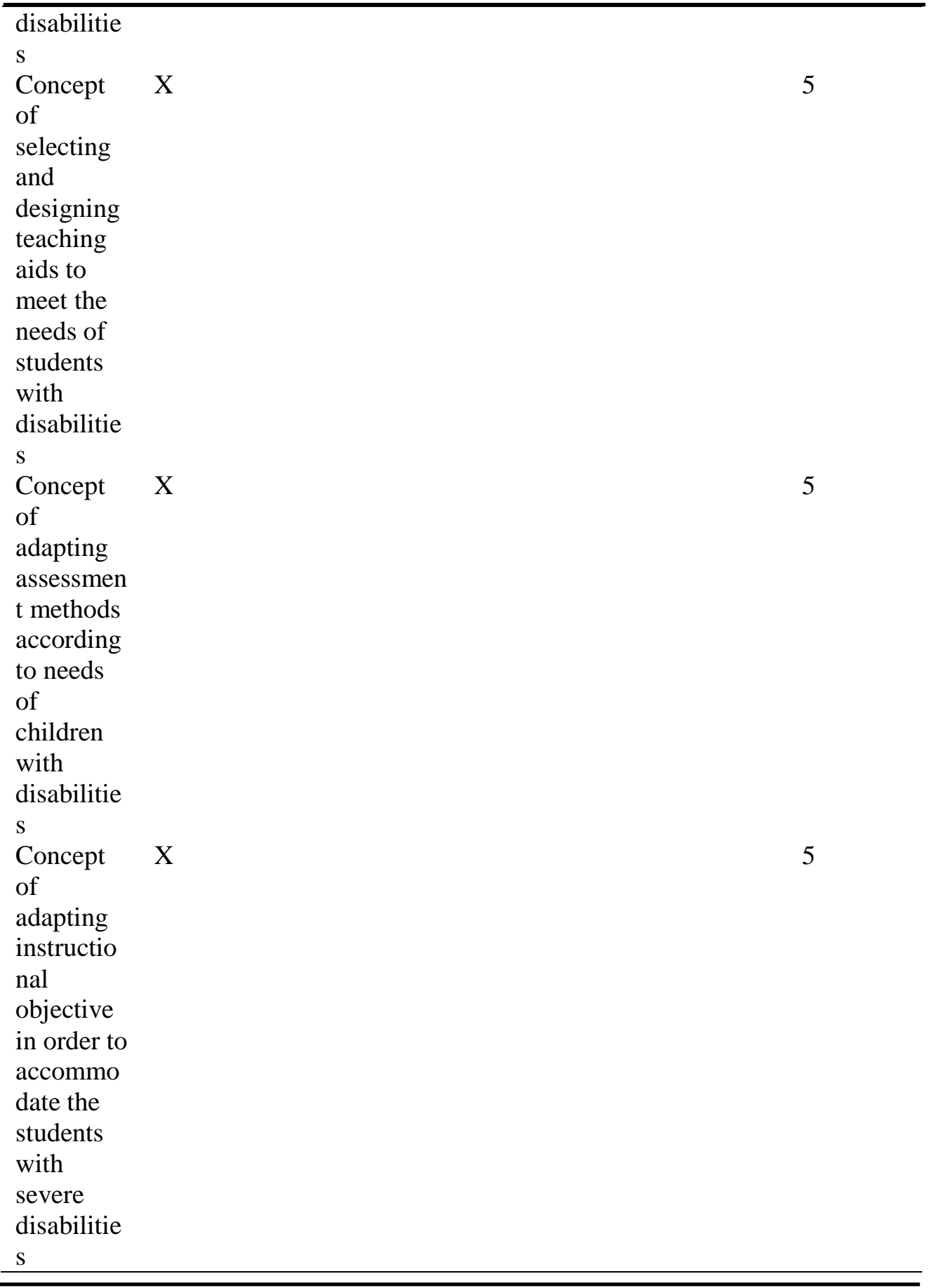


PJER, Vol 4, Issue 4 (2021)

Analysis of the...

\begin{tabular}{|c|c|c|c|c|c|c|c|}
\hline $\begin{array}{l}\text { Concept } \\
\text { of } \\
\text { addressin } \\
\mathrm{g} \\
\text { disabilitie } \\
\mathrm{s} \text { in lesson } \\
\text { planning }\end{array}$ & $X$ & $X$ & & $\begin{array}{l}\text { Child } \\
\text { developme } \\
\text { nt }\end{array}$ & $\begin{array}{l}\text { Addressi } \\
\text { ng } \\
\text { special } \\
\text { needs in } \\
\text { the } \\
\text { classroo } \\
\text { m }\end{array}$ & 49 & 2 \\
\hline $\begin{array}{l}\text { Concept } \\
\text { of } \\
\text { differentia } \\
\text { tion in } \\
\text { instructio } \\
n\end{array}$ & & & $X$ & $\begin{array}{l}\text { Classroom } \\
\text { Manageme } \\
\text { nt }\end{array}$ & $\begin{array}{l}\text { Curriculu } \\
\mathrm{m} \text { and } \\
\text { classroo } \\
\mathrm{m} \\
\text { managem } \\
\text { ent }\end{array}$ & 104 & 4 \\
\hline $\begin{array}{l}\text { Concept } \\
\text { of } \\
\text { addressin } \\
\text { g } \\
\text { individual } \\
\text { need of } \\
\text { students } \\
\text { in one } \\
\text { classroom }\end{array}$ & & $X$ & & $\begin{array}{l}\text { Classroom } \\
\text { manageme } \\
\text { nt }\end{array}$ & $\begin{array}{l}\text { Routine, } \\
\text { schedules } \\
\text { and time } \\
\text { managem } \\
\text { ent in } \\
\text { diverse } \\
\text { classroo } \\
\text { ms }\end{array}$ & 104 & 4 \\
\hline $\begin{array}{l}\text { Concept } \\
\text { of giving } \\
\text { children } \\
\text { with } \\
\text { disabilitie } \\
\text { s access } \\
\text { to general } \\
\text { curriculu } \\
\text { m }\end{array}$ & & $X$ & & $\begin{array}{l}\text { Child } \\
\text { developme } \\
\text { nt }\end{array}$ & $\begin{array}{l}\text { Addressi } \\
\text { ng } \\
\text { special } \\
\text { needs in } \\
\text { the } \\
\text { classroo } \\
\text { m }\end{array}$ & 50 & 5 \\
\hline $\begin{array}{l}\text { Concept } \\
\text { of using } \\
\text { assistive } \\
\text { technolog } \\
\text { y for } \\
\text { students } \\
\text { with } \\
\text { disabilitie } \\
\text { s }\end{array}$ & & $X$ & & $\begin{array}{l}\text { Informatio } \\
\mathrm{n} \text { and } \\
\text { Communic } \\
\text { ation } \\
\text { Technologi } \\
\text { es (ICTs) } \\
\text { in } \\
\text { Education }\end{array}$ & $\begin{array}{l}\text { Evaluatin } \\
\text { g ICT } \\
\text { Tools } \\
\text { and } \\
\text { Resource } \\
\text { s for Use. } \\
\text { for } \\
\text { Blinds; } \\
\text { Technolo } \\
\text { gies to }\end{array}$ & 166 & 3 \\
\hline
\end{tabular}




\begin{tabular}{|c|c|c|c|c|c|}
\hline & & & $\begin{array}{l}\text { assist } \\
\text { Special } \\
\text { Educatio } \\
\text { n) }\end{array}$ & & \\
\hline $\begin{array}{l}\text { Concept } \\
\text { of } \\
\text { reflecting } \\
\text { upon own } \\
\text { teaching } \\
\text { practices }\end{array}$ & $X$ & $\begin{array}{l}\text { Teaching } \\
\text { practicum }\end{array}$ & $\begin{array}{l}\text { The } \\
\text { teaching } \\
\text { practicu } \\
\text { m }\end{array}$ & 228 & 1 \\
\hline $\begin{array}{l}\text { Concept } \\
\text { of } \\
\text { transition } \\
\text { al } \\
\text { planning }\end{array}$ & & & & & 5 \\
\hline
\end{tabular}

The above table indicates that the concept of curriculum adaptation for students with disabilities, adapting the content to meet the needs of students with disabilities, designing instruction to meet the needs of students with disabilities, selecting and designing teaching aids to meet the needs of students with disabilities, adapting assessment methods according to the needs of children with disabilities and adapting instructional objectives in order to accommodate the students with severe disabilities were not evident in any course as reported by all respondents. The concept of addressing children with disabilities in lesson planning was reported to be somewhat evident in the course of child development by three respondents and concept of differentiation of instruction was reported to be clearly evident at topic level in the course of classroom management by four respondents. The concept of addressing individual needs was reported to be evident by three respondents in the course of classroom management under the topic of routine, schedules and time management in diverse classrooms while the concept of giving children with disabilities access to general curriculum was reported to be somewhat evident in the course of child development under the topic of addressing special needs in the classroom by all respondents. The concept of using assistive technology was reported to be somewhat evident by 3 respondents in the course of information and communication technologies in education under the topic of evaluating ICT tools and resources for use for Blinds.

Table No 4: Evidence of The Concept of Working in Collaboration with Parents and Professional to Create Inclusive Environment in the HEC-ETE Curriculum

\begin{tabular}{lllllllc}
\hline Indicators & $\begin{array}{l}\text { Not } \\
\text { Evide }\end{array}$ & $\begin{array}{l}\text { Somew } \\
\text { hat }\end{array}$ & $\begin{array}{c}\text { Clear } \\
\text { ly }\end{array}$ & Course & Topic & $\begin{array}{c}\text { Pa } \\
\text { ge }\end{array}$ & $\begin{array}{c}\text { No. of } \\
\text { Respond } \\
\text { ents }\end{array}$ \\
\hline
\end{tabular}




\begin{tabular}{|c|c|c|c|c|c|c|c|}
\hline & & $\begin{array}{l}\text { Eviden } \\
\mathbf{t}\end{array}$ & $\begin{array}{c}\text { Evide } \\
\text { nt }\end{array}$ & & & & \\
\hline $\begin{array}{l}\text { Concept of } \\
\text { collaborati } \\
\text { ng with } \\
\text { parents for } \\
\text { education } \\
\text { of children } \\
\text { with } \\
\text { disabilities }\end{array}$ & & $\mathrm{X}$ & & $\begin{array}{l}\text { Classroom } \\
\text { Assessme } \\
\text { nt }\end{array}$ & $\begin{array}{l}\text { Practice: } \\
\text { feedbac } \\
\mathrm{k} \text { to } \\
\text { students } \\
\text { and } \\
\text { assessm } \\
\text { ent } \\
\text { results } \\
\text { to } \\
\text { parents. }\end{array}$ & 187 & 2 \\
\hline $\begin{array}{l}\text { Concept of } \\
\text { working } \\
\text { with co- } \\
\text { teachers for } \\
\text { inclusion } \\
\text { of children } \\
\text { with } \\
\text { disabilities }\end{array}$ & & $X$ & & $\begin{array}{l}\text { The } \\
\text { developm } \\
\text { ental } \\
\text { practicum }\end{array}$ & $\begin{array}{l}\text { Taking } \\
\text { an } \\
\text { active } \\
\text { role in } \\
\text { co- } \\
\text { planning } \\
\text { and co- } \\
\text { teaching } \\
\text { sections } \\
\text { of a } \\
\text { lesson } \\
\text { alongsid } \\
\text { e your } \\
\text { cooperat } \\
\text { ing } \\
\text { teachers }\end{array}$ & 173 & 2 \\
\hline $\begin{array}{l}\text { Concept of } \\
\text { working } \\
\text { with } \\
\text { related } \\
\text { service } \\
\text { professiona } \\
\text { ls (speech } \\
\text { therapist, } \\
\text { physiothera } \\
\text { pist, } \\
\text { occupation } \\
\text { al therapist, } \\
\text { prosthetic }\end{array}$ & $X$ & & & & & & \\
\hline
\end{tabular}




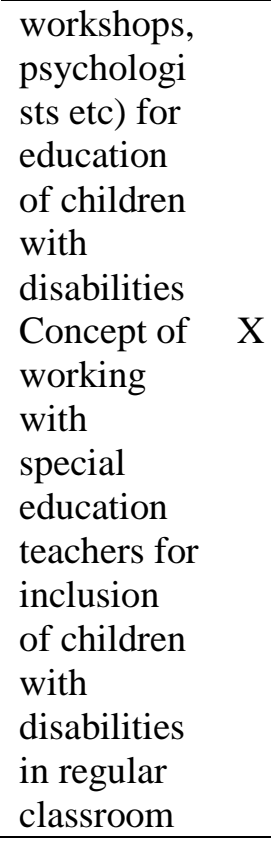

The above table indicates that the concept of collaborating with parents for education of children with disabilities was reported to be evident in the course of classroom assessment under the topic 'feedback to students and assessment results to parents' by one respondent. In the remarks section, the respondent reported that this concept is present with reference to general education classroom and student with disabilities have not been mentioned. Similarly, the concept of working with co-teachers was reported to be evident in the course of the developmental practicum with the topic of taking an active role in co-planning and co-teaching sections of a lesson alongside your cooperating teachers with reference to typical students. Both raters reported that students with disabilities or special needs were not mentioned in the course. The concept of working with related professional (speech therapists, physiotherapists, occupational therapist, prosthetic workshops, psychologists etc.) and the concept of working with special education teachers for education of children with disabilities were unanimously reported to be not evident.

Table No 5: Evidence of the concept of personal professional development of teachers in HEC-ETE curriculum

\begin{tabular}{|c|c|c|c|c|c|c|c|}
\hline $\begin{array}{l}\text { Indicator } \\
\mathrm{S}\end{array}$ & $\begin{array}{l}\text { Not } \\
\text { Evid } \\
\text { ent }\end{array}$ & $\begin{array}{l}\text { Somew } \\
\text { hat } \\
\text { Eviden }\end{array}$ & $\begin{array}{c}\text { Clear } \\
\text { ly } \\
\text { Evid } \\
\text { ent }\end{array}$ & Course & Topic & $\begin{array}{c}\text { Pa } \\
\text { ge } \\
\text { No. }\end{array}$ & $\begin{array}{c}\text { No. of } \\
\text { Respond } \\
\text { ents }\end{array}$ \\
\hline
\end{tabular}




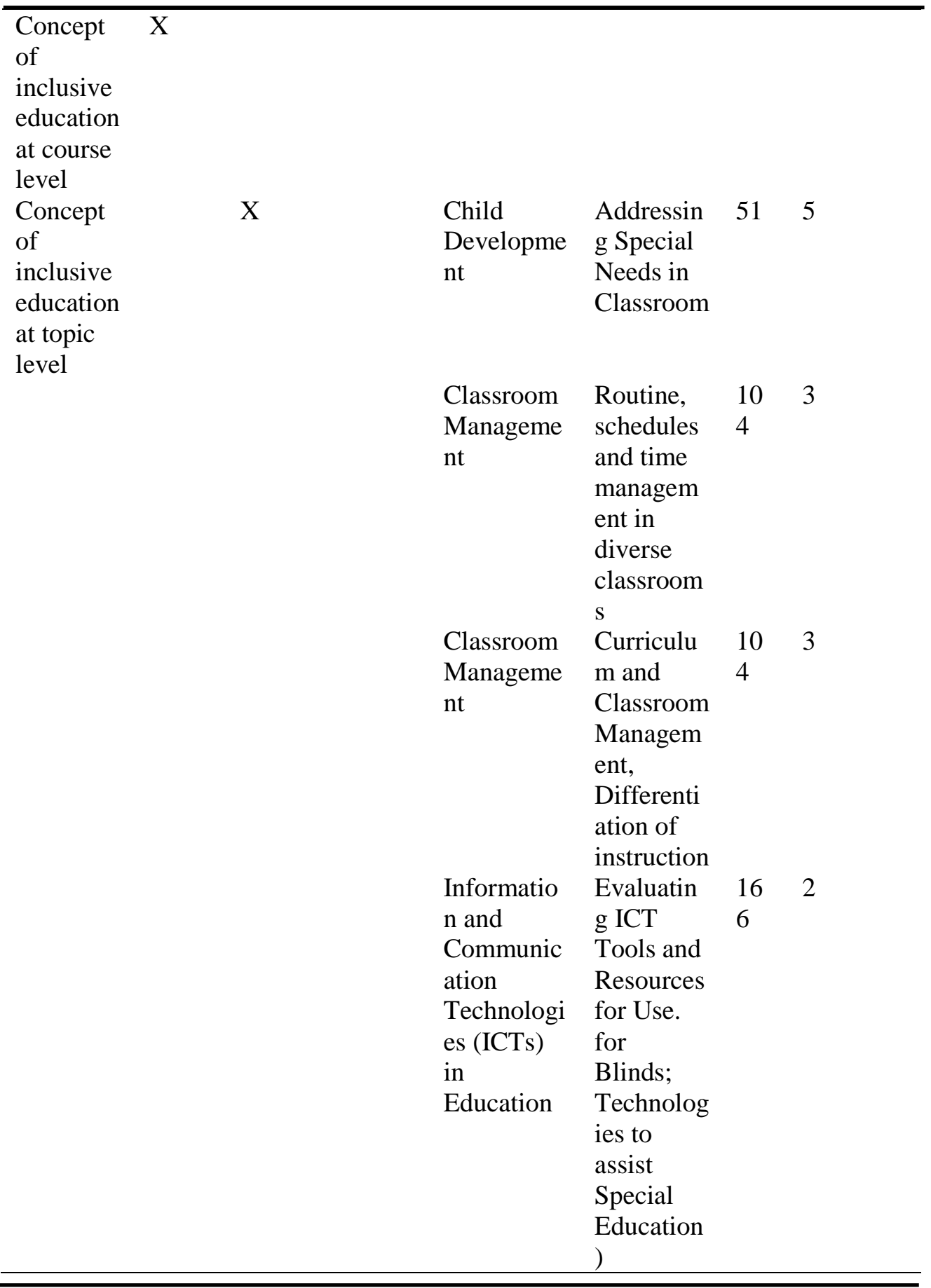


PJER, Vol 4, Issue 4 (2021)

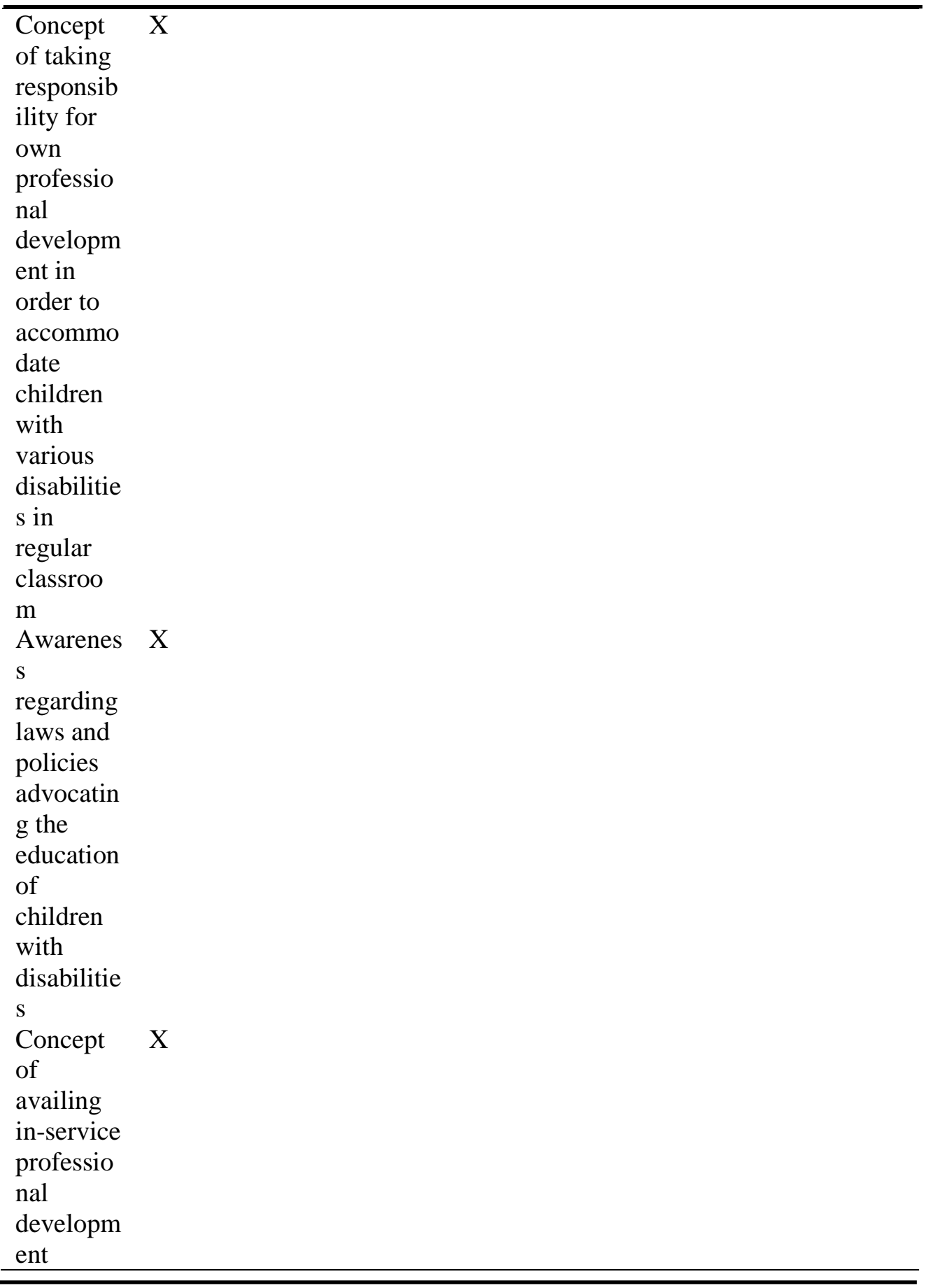




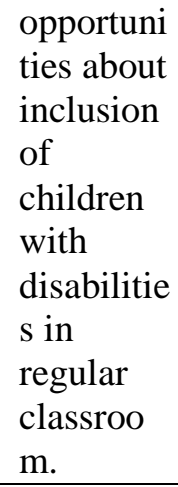

The above table indicates that the concept of inclusive education was reported to be somewhat evident at topic level in course of child development under the topic of addressing special needs in classroom, in the course of classroom management under the topic of routine, schedules and time management in diverse classrooms and curriculum and classroom management, differentiation of instruction and in the course of ICT in education under the topic evaluating ICT tools and resources for use. For blinds; technologies to assist special education. The concept of taking responsibility for own professional development in order to accommodate children with various disabilities in regular classroom, Awareness regarding laws and policies advocating the education of children with disabilities and the concept of availing in-service professional development opportunities about inclusion of children with disabilities in regular classroom were unanimously reported to be not evident in the HEC-ETE curriculum.

On the basis of the findings of this study, it may be concluded that HEC elementray teacher education curriculum doest no prepare the prospective elementary school teacher to include the students with disabilities in their classrooms though the content on disabilitiy is somewhat present in the HEC curriculum document. Furthermore, the analysis found out that the HEC elementary teacher education curriculum document does talk about atypical development, but it does not give necessary awareness to the prospective teachers about the full course of disabilities and human diversity. The concept of curriculum adaptation for special needs and inclusive classroom practices is not appropriately covered in HEC elementary teacher education curriculum although the concept of classroom management for diversity and use of ICT for visually impaired students is somewhat mentioned in the curriculum. The concept of working in collaboration with parents, professionals and community is also absent from the curriculum document. The concept of personal professional development to meet the ever emerging needs of the students with special needs is not present in the curriculum document. 


\section{DISCUSSION}

Results of the curriculum analysis and survey found that HEC elementary teacher education program does not appropriately prepare the elementary school teachers to accommodate children with disabilities in regular classroom. Analysis of the curriculum of HEC revealed that it cannot be claimed that the content about disability is completely missing from the curriculum. Topics on atypical development and accommodating the needs of children with disabilities were reported to be somewhat present three courses. As noted by Lautenbach \& Heyder (2019) in a review of studies on attitudes of pre-service teachers about inclusive education that different teacher education programs do include information on law and policy, categories of disability and inclusive classroom practices with an aim to develop positive attitudes towards inclusion of children with disabilities.

On the other hand, elementary school teachers reported that they were not prepared to accommodate children with disabilities in regular classrooms. This situation depicts that the contents given in the existing HEC elementary teacher education curriculum do not cover the awareness on disability and diversity and the practices required to accommodate the disability and other forms of human diversity in regular classroom. Similarly, Thakur \& Abbas (2017), Fazal (2012) and Pasha (2012) reported that teacher education programs in Pakistan do not prepare the teachers for inclusion of children with disabilities in regular classroom. Hick, et al. (2019), Robinson (2017) and Atta, Shah \& Khan (2009) argued that the teacher education programs should capacitate the teachers to accommodate the children with disabilities in regular classroom.

Comparison of the result of the present study and previous studies helps us to understand that teacher education programs should enable the teachers to accommodate children with disabilities and in the local context, already existing elementary teacher education programs are not fulfilling this duty. The results of the present study further depict that the elementary teacher education curriculum does not develop the understanding of disability and human diversity as perceive by the elementary school teachers as noted by Whitworth (1999) and Smith \& Marling (2012) that the diversity, disability or differences of the students should be made part of the content of general teacher education programs. Treating them differently or as something additional creates a divide in the teacher education for special education and general education. This divide already exists in the Pakistani context as the National Accreditation Council for Teacher Education (NACTE) and HEC treat both strands of teacher education as different disciplines. Results also indicate that elementary teacher education program does not enable the teachers to work in collaboration with parents, special education and related service professionals. European Agency for Development in Special Needs Education (2012) argued that 
teacher education programs should make teachers able to work with others (parents, professionals) to create enabling environments. LePage et al. (2010) and Whitsworth (1999) also proposed that training for working in collaborations with other professionals should be part of teacher education programs. On the basis of the results of the present study, it can also be concluded that elementary teacher education program does not develop the attitude of personal professional development to meet the emerging pedagogical needs of students with disabilities or diverse needs in regular classroom.

Hollenweger et al. (2015), Hick et al. (2019) and EADSNE (2012, 2015) emphasize that the teacher education curriculum must help the teachers to develop an attitude of personal professional development to meet the emerging pedagogical needs of diverse learners and to assume the identity of an inclusive practitioner. Literature further suggests that the most intense challenge faced by the developing countries in inclusion education reform is unpreparedness of the teachers who are responsible to teach in classroom with a heterogenous group of students (Sharma et al., 2015). Researches have demonstrated that in order to assume the role of inclusive education practitioners, teacher must be appropriately trained (Charema, 2010).

\section{RECOMMENDATIONS}

1. The Higher Education Commission of Pakistan (HEC) may adopt an Inclusive Model of Elementary Teacher Education (IMETE) for future upgrading of existing elementary teacher education programs in the universities and teacher education institutes across the country.

2. The National Accreditation Council for Teacher Education (NACTE) should also adopt the inclusive model of teacher education as a program improvement agenda for the future. The NACTE should make the inclusiveness of a teacher education program as one of the criteria for accreditation of a teacher education program.

3. The HEC and NACTE should conduct an Inclusive Education Audit of the existing teacher education programs across the country and require that the teacher education institutes may make the inclusive education a part of the general teacher education programs.

4. An in-service teacher training program should be launched to equip the existing elementary school teachers on the knowledge, skills and attitudes regarding inclusive education by Quaid Academy for Educational Development (QAED) at provincial and district level.

\section{REFERENCES}

Ariav, T. (1986). Curriculum analysis and curriculum evaluation: A contrast. Studies in 
Educational Evaluation, 12 (2), 139-147. doi: 10.1016/0191-491x(86)90003-9

Atta, M. A., Shah, M., \& Khan, M. M. (2009). Inclusive school and inclusive teacher. The Dialogue, 4(2), 272-283.

Avramidis, E., and E. Kalyva. (2007). The influence of teaching experience and professional development on Greek teachers' attitudes towards inclusion. European Journal of Special Needs Education 22: 367-89.

Ayre, C., \& Scally, A. J. (2014). Critical values for Lawshe's content validity ratio: revisiting the original methods of calculation. Measurement and Evaluation in Counseling and Development, 47(1), 79-86.

Batsiou, S., E. Bebetsos, P. Panteli, and P. Antoniou. 2008. Attitudes and intention of Greek and Cypriot primary education teachers towards teaching pupils with special educational needs in mainstream schools. International Journal of Inclusive Education 12: 201-19.

Beacham, N., \& Rouse, M. (2012). Student teachers' attitudes and beliefs about inclusion and inclusive practice. Journal of Research in Special Educational Needs, 12(1), 3-11. https://doi.org/10.1111/j.1471-3802.2010.01194.X

Charema, J. (2010). Inclusion of primary school children with hearing impairments in Zimbabwe. Africa Education Review, 7(1), 85-106. doi: 10.1080/18146627.2010.485810

Cochran-Smith, M., \& Dudley- Marling Marling, C. (2012). Diversity in Teacher Education and Special Education. Journal of Teacher Education, 63(4), 237-244. doi: $10.1177 / 0022487112446512$

De Boer, A., Pijl, S. J., \&Minnaert, A. (2011). Regular primary schoolteachers' attitudes towards inclusive education: A review of the literature. International journal of inclusive education, 15(3), 331-353.

European Agency for Development in Special Needs Education. 2011. Teacher Education for Inclusion across Europe - Challenges and Opportunities. Odense, Denmark: Author.

European Agency for Development in Special Needs Education. 2011. Teacher Education for Inclusion across Europe - Challenges and Opportunities. Odense, Denmark: Author.

European Agency for Special Needs and Inclusive Education. (2015). EMPOWERING TEACHERS TO PROMOTE INCLUSIVE EDUCATION: Conceptual Framework and Methodology.

Fazal, R. (2012). Readiness for Inclusion in Pakistani Schools: Perceptions of School Administrators. International Journal of Social Sciences and Education Mine Coins - Make Money: Http://Bit.ly/money_crypto, 2(4), 825-832. Retrieved from http://ijsse.com/

Forlin, C., \& Chambers, D. (2017). Catering for Diversity: Including Learners with Different Abilities and Needs in Regular Classrooms. Education in the Asia- Pacific Region: Issues, Concerns and Prospects, 555-571. https://doi.org/10.1007/978981-10-3654-5_33

Ghanizadeh, A., Bahredar, M. J., \&Moeini, S. R. (2006). Knowledge and attitudes towards attention deficit hyperactivity disorder among elementary school teachers. Patient Education and Counseling, 63(1-2), 84-88. doi:10.1016/j.pec.2005.09.002

Gul, F. (2015). Evaluating Entrepreneurial Skills of Students in Technical and Vocational Education and Training (TVET) Institutes (Unpublished doctoral dissertation). 
University of the Punjab, Lahore.

Hameed, A. \& Manzoor, A. (2014). Making children visible as right bearers for education. Husain, A., Masih, A., Husain, I. and Bhatia, H.K. (Edts.). Education as a Right Across the Levels: Challenges, Opportunities and Strategies. New Delhi.

Hick, P., Matziari, A., Mintz, J., Murchú, F. Ó., Cahill, K., Hall, K., Curtin4, C., \& Solomon, Y. (2019). Initial Teacher Education for Inclusion Final Report to the National Council for Special Education. Cambridge University Press, 53(9), 1689-1699. https://doi.org/10.1017/CBO9781107415324.004

Hollenweger, J., Pantić, N., \& Florian, L. (2015). Tool to Upgrade Teacher Education Practices for Inclusive Education. 70. https://pjpeu.coe.int/documents/1473702/8927135/Tool+to+Upgrade+Teach er+Education+Practices+for+Inclusive+Education/0cf28c1b-4f95-49ab9fd3-de77b772ffed\%0Ahttps://pjp-eu.coe.int/en/web/inclusiveeducation/documents

Jansen, J. D., \& Reddy, V. (1994). Curriculum analysis. In Workshop entitled 'Curriculum Development' held at the Peninsula Technikon, Cape Town, South Africa (Unpublished).

Lautenbach, F., \& Heyder, A. (2019). Changing attitudes to inclusion in preservice teacher education: a systematic review. Educational Research, 61(2), 231-253. https://doi.org/10.1080/00131881.2019.1596035

Lautenbach, F., \& Heyder, A. (2019). Changing attitudes to inclusion in preservice teacher education: a systematic review. Educational Research, 61(2), 231-253. https://doi.org/10.1080/00131881.2019.1596035

LePage, P., Courey, S., Fearn, E., Benson, V., Cook, E., Hartmann, L., \& Nielsen, S. (2010). Curriculum Recommendations for Inclusive Teacher Education. International Journal of Whole Schooling, 6(2), 19-45.

McMillan, J. H. (2013). Sage handbook of research on classroom assessment. Los Angeles: Sage.

Pasha, S. (2012). Readiness of Urban Primary Schools for Inclusive Education in Pakistan. Journal of Research and Reflections in Education, 6(2), 113-128. Retrieved from http://www.ue.edu.pk/journal.asp

Robinson, D. (2017). Effective inclusive teacher education for special educational needs and disabilities: Some more thoughts on the way forward. Teaching and Teacher Education, 61(1), 164-178. doi: 10.1016/j.tate.2016.09.007

Rose, R. (2010). Confronting obstacles to inclusion: international responses to developing inclusive education. Routledge.

Samsujjaman. (2017). Principle and Significance of Teacher Education. International Journal of Engineering Development and Research, 5(2). doi: IJEDR1702310

Sharma, U., Simi, J., \& Forlin, C. (2015). Preparedness of pre-service teachers for inclusive education in the Solomon Islands. Australian Journal of Teacher Education, 40(5), 103-116. https://doi.org/10.14221/ajte.2015v40n5.6

Thakur, I., \& Abbas, F. (2017). Inclusive Education in Punjab: Challenges and Way Forward. Journal of Inclusive Education, 1(1), 20-35. Retrieved from http://journal.aiou.edu.pk/journal1/index.php/JIE/article/view/20/35 
Thakur, I., \& Abbas, F. (2017). Inclusive Education in Punjab: Challenges and Way Forward. Journal of Inclusive Education, 1(1), 20-35. Retrieved from http://journal.aiou.edu.pk/journal1/index.php/JIE/article/view/20/35

Van Mieghem, A., Verschueren, K., Petry, K., \&Struyf, E. (2018). An analysis of research on inclusive education: a systematic search and meta review. International Journal of Inclusive Education, 24(6), 675-689. https://doi.org/10.1080/13603116.2018.1482012

Welsh, M. E., \& D’Agostino, J. (2009). Fostering consistency between standards-based gradesand large-scale assessment results. Practical solutions for serious problems in standards-based grading, 75-104.

Whitworth, J. W. (1999). A Model for Inclusive Teacher Preparation. Electronic Journal for Inclusive Education, 1(2), 1-11. Retrieved from https://corescholar.libraries.wright.edu/ejie/vol1/iss2/3/ 